\author{
dr Ireneusz Lukasz ROSIEK \\ Uniwersytet Ekonomiczny w Poznaniu \\ e-mail: irekrosiek@gmail.com \\ ORCID: 0000-0003-3061-8314
}

DOI: $10.15290 /$ oes.2018.03.93.14

\title{
PODATEK OD TOWARÓW I USEUG W SPRAWOZDANIACH BUDŻETOWYCH JEDNOSTEK SAMORZĄDU TERYTORIALNEGO
}

\begin{abstract}
Streszczenie
Artykuł konfrontuje kwestie organizacyjne centralizacji rozliczeń VAT w jednostkach samorządu terytorialnego $\mathrm{z}$ ustawową zasadą ich gospodarki finansowej. Jednostki samorządu terytorialnego, mając swobodę w zakresie organizacji rozliczeń VAT, wspierają się wytycznymi Ministerstwa Finansów. Według tych wytycznych wpływy podatku od towarów i usług w formie zapłaty za świadczone usługi otrzymywanych od kontrahentów samorządowych jednostek budżetowych nie stanowią dochodu budżetowego. Podporządkowując się wytycznym, jednostki samorządu terytorialnego ewidencjonuja te środki finansowe, nie budżetując ich. W konsekwencji nie wykazują tych wpływów w sprawozdaniu budżetowym Rb-27S. Autor artykułu przekonuje, że taki sposób rozliczania wpływów nie jest zgodny z zasadami gospodarki finansowej jednostek budżetowych wyrażonymi w ustawie o finansach publicznych i podważa wiarygodność sprawozdań budżetowych.
\end{abstract}

Słowa kluczowe: finanse publiczne, budżet jednostek samorządu terytorialnego, centralizacja rozliczeń VAT, sprawozdawczość budżetowa

\section{THE CENTRALISATION OF VAT SETTLEMENTS IN LOCAL GOVERNMENT UNITS IN THE CONTEXT OF ITS FINANCIAL ECONOMY RULES}

\section{Summary}

The article confronts the organizational issues of centralization of VAT settlements in local government units with their financial economy principles. Local government units, having the freedom to organise VAT settlements, make use of the guidelines of the Ministry of Finance. According to these guidelines, the proceeds of VAT in the form of payment for services rendered from the contractors of organisational units should not be treated as the budget income. By complying with the guidelines, local government units record these financial resources without budgeting them. Consequently, they do not show these proceeds in the local budget income report (Rb-27S). The author of the article argues that this way of proceeds' settlement is not consistent with the principles of financial management of budgetary units expressed in the Public Finance Act and undermines the reliability of budget reports.

Keywords: public finance, regional government budget, centralisation of VAT settlement, budget reporting

JEL classification: $\mathrm{H} 71, \mathrm{H} 26, \mathrm{H} 72$ 


\section{Wstęp}

Niektóre z usług publicznych, które jednostki samorządu terytorialnego (jst) świadczą odpłatnie, w świetle ustawy o podatku od towarów i usług stanowią sprzedaż opodatkowana. Wpływy ze sprzedaży towarów i usług stanowią dochód budżetu jednostki samorządu terytorialnego ${ }^{1}$. Powstaje wówczas obowiazzek podatkowy. Problemem badawczym artykułu jest kwestia raportowania w sprawozdaniach budżetowych (Rb-27S) o wysokości osiągniętych dochodów przez jednostki samorządu terytorialnego z tytułu sprzedaży opodatkowanej VAT. Zasadniczym celem artykułu jest ustalenie, czy jednostki samorządu terytorialnego jako swój dochód powinny uznawać pełną kwotę otrzymaną od klienta z tytułu transakcji opodatkowanej VAT, czyli łącznie z podatkiem od towarów i usług, czy tylko kwotę netto. Osiagnięciu tego celu służy analiza przepisów prawa. Dodatkowym celem artykułu jest weryfikacja, czy praktyka stosowana przez jednostki samorządu terytorialnego przystaje do stanu prawnego. Konfrontacja obu tych celów powinna stanowić asumpt do dalszych badań dotyczących wiarygodności i porównywalności sprawozdań budżetowych jst w obszarze dochodów.

\section{Centralizacja rozliczeń VAT $\mathrm{w}$ jednostkach samorządu terytorialnego}

Transakcje stanowiące sprzedaż opodatkowana, a co za tym idzie uzyskiwane dochody, w rzeczywistości realizowane są przez poszczególne jednostki organizacyjne jst. W związku z istniejącym obowiązkiem podatkowym zasadniczą kwestią staje się sprecyzowanie, kto jest podatnikiem: jednostka samorządu terytorialnego jako całość, instytucjonalnie stanowiąca zbiór poszczególnych jednostek organizacyjnych, czy też każda z jej jednostek odrębnie.

Przez wiele lat funkcjonowania podatku od towarów i usług (dalej: podatku VAT) samorządowe jednostki budżetowe były uznawane za odrębnych, samodzielnych podatników podatku od towarów i usług ${ }^{2}$. Było tak do czasu, gdy ustawodawca wskazał, że podatnikiem podatku od towarów i usług jest jednostka samorządu terytorialnego. Od 2017 r. upowszechniono tę zasadę, która w praktyce funkcjonuje pod hasłem centralizacji rozliczeń VAT w jednostkach samorządu terytorialnego.

Istotą centralizacji rozliczeń VAT jest przyjęcie, że podatnikiem VAT jest jednostka samorządu terytorialnego. Z punktu widzenia ustroju samorządu, w ujęciu instytucjonalnym, jednostka samorządu terytorialnego jest zbiorem jej jednostek organizacyjnych, funkcjonujących w różnych formach organizacyjno-prawnych. Podstawowa forma jest jednostka budżetowa. Ta z kolei nie ma osobowości prawnej.

art. 5 ust. 2 pkt 3 i 4 ustawy z dnia 27 sierpnia 2009 r. o finansach publicznych w związku z art. 4 ust. 1 pkt 3 ustawy o dochodach jednostek samorządu terytorialnego.

2 Ustawa o podatku od towarów i usług (ustawa o VAT) wskazuje, że to właśnie samodzielność prowadzenia działalności przez podmiot warunkuje, czy może być on uznany za podatnika podatku VAT czy też nie (art. 15 ustawy o VAT). 
Dokonywane przez jednostki organizacyjne jst transakcje, które w świetle ustawy o podatku od towarów i usług stanowią sprzedaż opodatkowaną VAT, w sensie prawnym są sprzedażą dokonana przez jst, a nie przez jej jednostkę organizacyjną. Centralizacja rozliczeń VAT w obrębie jst nie obejmuje natomiast wszystkich jej jednostek organizacyjnych, a jedynie te działające w formie jednostek budżetowych i zakładów budżetowych [zob. Pyrz, 2015].

\section{Wytyczne Ministerstwa Finansów w zakresie centralizacji rozliczeń VAT}

W 2017 r. Ministerstwo Finansów opublikowało dodatkowe wyjaśnienia w zakresie centralizacji rozliczeń VAT. Przedmiotem wyjaśnień jest między innymi sposób prezentowania w budżecie jednostki samorządu terytorialnego dochodów opodatkowanych podatkiem VAT. Rozstrzygnięto wówczas czy dochody jst wynikające $z$ dokonywanej sprzedaży opodatkowanej VAT należy ujmować w sprawozdaniach budżetowych (RB-27S) w kwocie brutto wynikającej ze zrealizowanych płatności przez kontrahentów (tzw. kasowo zrealizowanych i zgodnie z wpływami wynikającymi z wyciagów bankowych), czy w kwocie netto pomniejszonej o podatek VAT należny.

Wywód w tej sprawie Ministerstwo Finansów oparło o stwierdzenie, że „podatek VAT nie stanowi dochodu jednostek samorządu terytorialnego. W katalogu źródeł dochodów jednostek samorządu terytorialnego, określonym w ustawie z dnia 13 listopada 2003 r. o dochodach jednostek samorządu terytorialnego, podatek VAT nie występuje jako źródło dochodów tych jednostek. Zgodnie z art. 1 ust. 2 ustawy z dnia 11 marca 2004 r. o podatku od towarów i usług podatek VAT jest dochodem budżetu państwa" [Ministerstwo Finansów, 2017]. Stwierdzenie to w ocenie autora artykułu nie budzi wątpliwości. Jest ono prawdziwe. Watpliwości wzbudza natomiast konkluzja sformułowana na podstawie tego wywodu, która mówi, że wobec powyższego w sprawozdaniu Rb-27S z wykonania planu dochodów budżetowych samorządowej jednostki budżetowej i jednostki samorządu terytorialnego dochody powinny być ujmowane w kwotach netto (bez podatku VAT)" [Ministerstwo Finansów, 2017].

\section{Zapłata za wykonanie usługi nie jest zapłatą podatku}

W ocenie autora artykułu, Ministerstwo Finansów popełniło zasadniczy błąd w publikowanych wytycznych przyjmując, że samorządowe jednostki budżetowe uzyskują wpływy podatkowe z tytułu VAT. Ministerstwo uznało, że wpłaty dokonywane przez kontrahentów jednostek budżetowych jst w kwocie netto stanowia zapłatę za wykonaną usługę lub nabyty towar, zaś doliczony do tej kwoty podatek VAT stanowi wpływ podatkowy. W rzeczywistości wpłaty kontrahentów dokonywane na rzecz jednostek budżetowych z tytułu transakcji opodatkowanych (lub nie) VAT, stanowią w całości zapłatę ceny za wykonaną usługę bądź dostawę towaru. Jak wskazał Sąd Najwyższy w Uchwale z dnia 21 lipca 2006 r. [Sygn. akt III CZP 
54/06], podatek VAT jest podatkiem cenotwórczym, co oznacza, iż wpływa on na wysokość ceny w sytuacji, gdy towar lub usługa podlega opodatkowaniu. Tym samym stanowi on element wynagrodzenia za wykonaną usługę bądź dostawę towaru. Podejście to jest zgodne $\mathrm{z}$ definicja ceny określona $\mathrm{w}$ art. 3 ustawy z dnia 9 maja 2014 r. o informowaniu o cenach towarów i usług, która mówi, że „w cenie uwzględnia się podatek od towarów i usług oraz podatek akcyzowy, jeżeli na podstawie odrębnych przepisów sprzedaż towaru (usługi) podlega obciążeniu podatkiem od towarów i usług lub podatkiem akcyzowym".

W umowach o charakterze cywilnoprawnym, której przedmiotem jest świadczenie usług lub dostawa towarów przez jednostkę sektora finansów publicznych obojętnie czy wskażemy jednostkę budżetową, czy jednostkę samorządu terytorialnego - występuje ona jako strona umowy. Otrzymując zapłatę za wykonanie przedmiotu tej umowy występuje $\mathrm{w}$ roli kontrahenta, a nie organu podatkowego. Nie ulega watpliwości, że wpływy stanowiące zapłatę za przedmiot umowy cywilnoprawnej, są uzyskaną ceną w pełnej wysokości, bez względu na to, czy składnikiem tej ceny sa podatki.

$\mathrm{Na}$ gruncie ustawy o finansach publicznych, wpływy te powinny stanowić dochód publiczny. Odrębną sprawą jest kwestia sposobu gospodarowania tymi wpływami.

\section{Zasady gospodarki finansowej jednostek budżetowych i jednostek samorządu terytorialnego}

Podstawową formą organizacyjno-prawną jednostek sektora finansów publicznych jest jednostka budżetowa. Jednostki organizacyjne jednostek samorządu terytorialnego są tworzone zasadniczo właśnie w tej formie. Art. 11 ustawy o finansach publicznych [Ustawa 2009] stanowi, że jednostki budżetowe nie posiadaja osobowości prawnej, a swoje wydatki pokrywają bezpośrednio z budżetu. Tym samym pobrane dochody odprowadzaja na rachunek dochodów budżetu państwa albo budżetu jednostki samorządu terytorialnego. Gospodarka finansowa opiera się o plan dochodów i wydatków. W skrócie można wskazać ogólną zasadę, że wpływy środków pieniężnych na rachunek jednostki budżetowej to dochody budżetowe, a wypływy środków z rachunku jednostki to wydatki budżetowe. Reguła ta jest odzwierciedleniem zasady kasowej, charakterystycznej dla sektora publicznego.

Paragraf 5 rozporządzenia Ministra Rozwoju i Finansów z dnia 13 września 2017 r. w sprawie rachunkowości oraz planów kont dla budżetu państwa, budżetów jednostek samorządu terytorialnego, jednostek budżetowych, samorządowych zakładów budżetowych, państwowych funduszy celowych oraz państwowych jednostek budżetowych mających siedzibę poza granicami Rzeczypospolitej Polskiej wskazuje, że „operacje dotyczące ich dochodów i wydatków są ujmowane w księgach rachunkowych na odrębnych kontach księgowych w zakresie faktycznie (kasowo) zrealizowanych wpływów i wydatków dokonanych na bankowych rachunkach budżetów oraz rachunkach bieżących dochodów i wydatków budżetowych jedno- 
stek budżetowych". Z powyższego zapisu wynika, że pełna kwota wpływu od kontrahenta jednostki powinna zostać ujęta jako dochód budżetowy i wykazana w sprawozdaniu Rb-27S.

Dochody publiczne są środkami publicznymi [Ustawa 2009, art. 5], których gromadzenie wymaga zaewidencjonowania w oparciu o tzw. klasyfikację budżetowa do odpowiedniego działu, rozdziału i paragrafu [Ustawa 2009, art. 39], a następnie raportowania w formie sprawozdań budżetowych [Ustawa 2009, art. 41]. Wśród dochodów publicznych są między innymi wpływy z najmu i dzierżawy [Ustawa 2009, art. 5] opodatkowane VAT.

Biorąc pod uwagę, że wpływy z tytułu transakcji stanowiących sprzedaż opodatkowaną VAT dokonywane na rachunek bieżący jednostki budżetowej jst stanowią dochód publiczny, powinny być one budżetowane i ujęte w planach finansowych jednostek, a co za tym idzie ujmowane również w sprawozdaniu RB-27S. W pełnej kwocie uzyskanych wpływów (otrzymanej ceny), czyli razem należnym podatkiem VAT.

Konsekwentnie zapłata zobowiązania podatkowego jednostki samorządu terytorialnego z tytułu VAT powinna być wydatkiem budżetowym ujętym w specjalnie do tego przeznaczonej podziałce klasyfikacji budżetowej, tj. w paragrafie 453. Stanowisko to potwierdzaja interpretacje Ministerstwa Finansów. Pierwsza z nich, została wydana dla Powiatu Bolesławieckiego w dniu 25 października 2017 r. (sygn. BP1. 4102.32.2017). Dwie kolejne potwierdzają tę zasadę i choć wydane są dla państwowych jednostek budżetowych, to dowodzą, że zobowiązań z tytułu VAT jednostki budżetowe nie powinny regulować bezpośrednio z uzyskiwanych wpływów33.

\section{Ujmowanie dochodów opodatkowanych VAT w sprawozdaniach budżetowych w praktyce jednostek samorządu terytorialnego}

Autor przeprowadził badanie ankietowe wśród samorządów województw, powiatów i miast na prawach powiatów. Spośród 396 jednostek stanowiących zbiorowość, uzyskał dane z 273, co stanowi 68,94\% badanej zbiorowości i 9,7\% jednostek samorządu terytorialnego w ogóle. Jedna jst ${ }^{4}$ wskazała, że nie jest podatnikiem VAT, korzystając ze zwolnienia podmiotowego na podstawie art. 113 ustawy o VAT. Dlatego ta ankieta nie jest przedmiotem dalszej analizy.

Celem badania było zweryfikowanie, czy jednostki dostosowały się do wyjaśnień Ministerstwa Finansów w zakresie nieuznawania VAT należnego za dochód budżetowy, a także ustalenie wielkości i dokonanie analizy kwot podatku VAT, które nie są budżetowane przez jst. Badanie odnosiło się do rozwiązań funkcjonujących w jst w roku budżetowym 2017, a dane uzyskano w trybie dostępu do informacji publicznej na wniosek.

\footnotetext{
3 Ministerstwo Finansów, pismo z dnia 30 listopada 2017 r. o sygn. BP1.4102.39.2017 oraz pismo z dnia 16 lutego 2018 r. o sygn. FG6.412.7.2018.KSS.

4 Powiat Górowski.
} 
Na pytanie ankietowe w brzmieniu: „Czy VAT od dokonanej sprzedaży opodatkowanej stanowi dochód budżetowy i był wykazywany w sprawozdaniu Rb-27S w roku 2017?” zdecydowana większość (235 jednostek) odpowiedziała negatywnie (tabela 1). Wydaje się, że odpowiedź na to pytanie potwierdza, że działania Ministerstwa Finansów w formie miękkich wyjaśnień odnośnie centralizacji VAT, choć nie stanowią źródeł prawa, silnie oddziałują na praktyki stosowane przez jst.

TABELA 1

Ujmowanie wartości podatku od towaru i usług od dokonanej sprzedaży opodatkowanej przez jednostki samorządu terytorialnego jako dochodu budżetowego w roku 2017

\begin{tabular}{|l|c|}
\hline \multicolumn{1}{|c|}{ Opcja odpowiedzi } & Liczba JST \\
\hline $\begin{array}{l}\text { TAK, VAT od dokonanej sprzedaży opodatkowanej stanowi dochód bu- } \\
\text { dżetowy i był wykazywany w sprawozdaniu Rb-27S w roku 2017 }\end{array}$ & 29 \\
\hline $\begin{array}{l}\text { NIE, VAT od dokonanej sprzedaży opodatkowanej nie stanowił dochodu } \\
\text { budżetowego i nie był wykazywany w sprawozdaniu Rb-27S w roku 2017 }\end{array}$ & 235 \\
\hline inna odpowiedź & 8 \\
\hline
\end{tabular}

Źródło: opracowanie własne na podstawie wyników badania ankietowego.

Tylko 30 jst jednoznacznie wskazało, że pełna kwota wpływu uzyskanego od kontrahenta $z$ tytułu transakcji stanowiących sprzedaż opodatkowaną (łącznie z VAT) jest uznawana za dochód budżetowy. Mimo niskiego odsetka jednostek praktykujących to rozwiązanie, wydaje się być ono prawidłowe w świetle argumentów przywołanych w poprzednich punktach artykułu.

Co ciekawe, 8 jednostek uznało, że odpowiedź na zadane pytanie ankietowe nie jest jednoznaczna. Autor artykułu przedstawi trzy argumenty tego twierdzenia, których treść wyraźnie obrazuje praktyki w zakresie centralizacji rozliczeń VAT.

Prezydent Miasta Zabrze stwierdził, że pytanie o to, czy VAT od sprzedaży opodatkowanej dokonywanej przez Miasto Zabrze stanowi dochód budżetowy nie stanowi informacji publicznej, bowiem nie jest to zagadnienie sfery faktów. Co więcej, na pytanie, czy podatek VAT od sprzedaży dokonywanej przez Miasto Zabrze był wykazywany w sprawozdaniu Rb-27S, Prezydent stwierdził, że nie jest w posiadaniu tej informacji. Wskazał także, że informację taka posiadaja jednostki organizacyjne Miasta Zabrze i to do nich indywidualnie należy zwrócić się z wnioskiem o udzielenie tej informacji [Prezydent Miasta Zabrze, 2018]. Odpowiedź ta nasuwa pytanie, czy oby na pewno w tej jednostce samorządu terytorialnego centralizacja rozliczeń VAT ma w ogóle miejsce.

Miasto Gorzów Wielkopolski wskazało, że jedynie gdy wpływ zwrotu VAT-u za dany rok budżetowy wpłynął w roku kolejnym, wówczas kwota ta stanowiła dochód budżetowy. Natomiast VAT należny (od dokonanej sprzedaży opodatkowanej) w roku bieżącym nie jest uznawany za dochód budżetowy. Niewykluczone, 
że podobne rozwiązanie przyjęto w dwóch innych jst, które na to samo pytanie ankietowe odpowiedziały jedynie „częściowo tak”. Powiat Kwidzyński stwierdził natomiast, że „VAT od sprzedaży opodatkowanej generalnie nie stanowi dochodu budżetu powiatu; stanowi dochód tylko w sytuacji gdy VAT z tytułu zakupu usługi bądź towaru jest ściśle związany ze sprzedażą opodatkowaną".

Jeżeli chodzi o jst, które niejednoznacznie odpowiedziały, czy VAT od sprzedaży opodatkowanej stanowi dochód budżetowy, to złożoność rozwiązań opisana przez jednostki stanowi cenną wskazówkę. Choć trudno formułować szczegółowe wnioski z informacji uzyskanej z ankiety, to można domniemać, że wpływ VAT-u od dokonanej przez jst sprzedaży opodatkowanej jest budżetowany tylko wówczas, gdy nie musi być on w pełnej wysokości ,oddany” do urzędu skarbowego. W sytuacji gdy jst „zatrzyma” choćby część kwoty VAT należnego uzyskanego jako zapłatę ceny przez kontrahenta $z$ transakcji opodatkowanej ${ }^{6}$, to wówczas zachodzi wręcz konieczność uznania VAT-u należnego za dochód budżetowy. Dokładnie na takie rozwiązanie wskazała Gmina Wrocław, w której VAT należny stanowi dochód budżetowy „w wysokości kwoty podatku należnego, który nie został przekazany na rachunek urzędu skarbowego ze względu na jego pomniejszenie o kwotę podatku naliczonego".

Choć przeważająca liczba jednostek samorządu terytorialnego dostosowała się do wytycznych Ministerstwa Finansów w zakresie nieujmowania jako dochódu budżetowego części wpływów stanowiących wpłaty z transakcji opodatkowanych VAT w kwocie VAT należnego, to z badania wynika, że nie ma pełnej jednorodności w względzie. To oznacza, że informacje o dochodach jednostek samorządu terytorialnego wykazywane w sprawozdaniach $\mathrm{Rb}-27 \mathrm{~S}$ są obarczone błędem, a analizy porównawcze sprawozdań jst moga prowadzić do nieprawdziwych wniosków.

Wielkość błędu sprawozdań budżetowych, wynikającą z nieujmowania pełnego dochodu budżetowego ze sprzedaży opodatkowanej, można szacować w zakresie od 8 do około $20 \%$, biorąc pod uwage aktualnie obowiązujące stawki podatkowe, ale tylko w odniesieniu do dochodów ze sprzedaży opodatkowanej.

Autor artykułu podjął starania aby zmierzyć ten błąd w wartościach nominalnych przez analizę wartości VAT należnego uzyskiwanego w $2017 \mathrm{r}$. przez badane jst $\mathrm{i}$ ich konfrontację z wysokością zobowiązania podatkowego, czyli kwotą VAT, która faktycznie powinna być wpłacona przez jst do urzędu skarbowego ${ }^{7}$.

\footnotetext{
Powiat Kłodzki i Wysokomazowiecki.

6 Jest to możliwe wówczas, gdy jst dokona stosowanego odliczenia podatkowego (zobowiązanie podatkowe VAT to zasadniczo kwota VAT należnego pomniejszona o VAT naliczony).

7 W badaniu ankietowym zapytano o sumę kwot podatku VAT należnego ze wszystkich deklaracji miesięcznych roku 2017 oraz oddzielnie o sumę kwot zobowiązania podatkowego VAT ze wszystkich deklaracji miesięcznych. Zastosowano tu pewne uproszczenie, w którym wynik badania nie pokazuje zobowiązań podatkowych w poszczególnych miesiącach (w niektórych miesiącach może powstać zobowiązanie podatkowe, a w niektórych nadpłata, co w rozrachunku rocznym nie jest widoczne). Dane w zakresie rozliczeń VAT w 2017 r. uzyskano w ankiecie na podstawie deklaracji miesięcznych VAT-7 i VAT-7K, stąd dane finansowe prezentują wartości w ujęciu memoriałowym, a nie kasowym.
} 
W ankiecie zapytano o wysokość podatku VAT należnego ujętego w deklaracjach rozliczeniowych jst w roku 2017. Analizy dokonano w oparciu o dane z 270 jednostek $^{8}$.

Łączna kwota podatku VAT stanowiącego wpływy z transakcji opodatkowanych w grupie 270 analizowanych jst wynosiła 918.387 .642 zł w 2017 r. Z tej kwoty 759.797.570 zł nie zostało zabudżetowane przez jst jako dochód budżetowy (82,73\%). 10 jednostek samorządu terytorialnego objętych badaniem prawdopodobnie nie korzysta z prawa do pomniejszenia zobowiązania podatkowego o VAT naliczony związany ze sprzedażą opodatkowaną - są to jednostki, które wskazały taką samą kwotę VAT należnego, jak i zobowiazzania podatkowego. 7 jednostek jako kwotę zobowiazzania podatkowego VAT w 2017 r. wskazało zero, co oznacza, że jednostki te w całości zatrzymują uzyskany od kontrahentów VAT należny. Z kolei 8 jednostek wpłaca do urzędów skarbowych kwotę podatku wyższą niż wartość VAT należnego, co może być wynikiem rozliczania tzw. odwróconego VAT.

Średnia wartość podatku VAT należnego uzyskanego przez jst to 3.413.520,65 zł w skali roku, a średnia roczna wartość zobowiązania podatkowego to 1.060.746,67 zł. Wynika z tego, że z każdej 1 złotówki wpływu VAT należnego, stanowiącego cenę za sprzedaż opodatkowaną dokonywana przez jst, 31 groszy było przez nią oddawana do urzędu skarbowego, natomiast pozostałe 69 groszy pozostawało w dyspozycji jst. Przy czym najczęściej (mediana) wartość zobowiązania podatkowego była mniejsza niż wartość VAT należnego o 21,41\%.

\section{Skutki}

Konsekwencją dostosowania się przez jednostki samorządu terytorialnego do stanowiska Ministerstwa Finansów jest stan, w którym część środków publicznych nie jest budżetowana. Samorządowe jednostki budżetowe, które otrzymują wpływy od kontrahentów w kwocie brutto z tytułu sprzedaży opodatkowanej, wartość netto wpływu uznaja za dochód budżetowy, przekazuja jednostce nadrzędnej i wykazują w sprawozdawczości budżetowej. Część stanowiąca VAT funkcjonuje w obiegu pomiędzy jednostką budżetową a jednostką nadrzędną jako środki pozabudżetowe. Najpierw środki te sa przekazywane do jednostki nadrzędnej, aby ta mogła dokonać zapłaty podatku VAT zgodnie ze złożoną deklaracją VAT-7, po czym przynajmniej część przekazanych środków na zapłatę VAT wraca do pierwotnej jednostki, zmniejszając jej wydatki bieżące. Dzieje się tak dlatego, że wpłacony przez kontrahentów VAT należny często nie jest wpłacany do Urzędu Skarbowego w pełnej wysokości. Zgodnie z zasadą przerzucalności podatku [zob. Bucior, 2016], jednostka samorządu terytorialnego ma prawo od podatku należnego odliczyć podatek

8 Badaniem objęto 273 jst, z czego Powiat Górowski jest zwolniony z VAT, Powiat Żywiecki odmówił udostępnienia danych, twierdząc że stanowią one tajemnicę skarbową, natomiast Powiat Kielecki wskazał wartość VAT należnego w kwocie ujemnej, tj. -446.686 zł, co może wpłynąć negatywnie na rzetelność badania i stąd został wykluczony przez autora artykułu z badania. 
naliczony, o ile jest on związany ze sprzedażą opodatkowaną. W ten sposób w jednostkach samorządu terytorialnego powstaje obieg pieniężny pomiędzy urzędem jst a jednostkami podległymi, który nie jest budżetowany jako dochód budżetowy, a częściowo finansuje wydatki budżetowe.

T. Famulska i B. Rogowska-Rajda wskazują, że „trudno jednoznacznie ocenić wpływ centralizacji rozliczeń na finanse JST z uwagi na specyfikę ich działania. Część jednostek samorządu terytorialnego może odnotować dodatkowe dochody w postaci zwiększonych zwrotów VAT, część natomiast dodatkowe koszty w postaci zwiększonych wpłat zobowiązania podatkowego z tytułu VAT" [Famulska, Rogowska-Rajda, 2017, s. 120]. Wyniki przeprowadzonego badania pokazują, że nieliczne jednostki samorządu terytorialnego potencjalnie mogą wykazywać nadwyżkę VAT i ubiegać się o zwrot. Dodatkowym dochodem dla jst nie są zatem zwroty VAT, a różnica pomiędzy wpływami VAT należnego stanowiącymi element ceny z transakcji opodatkowanej VAT, a odliczeniami VAT od dokonanych zakupów powiązanymi ze sprzedażą opodatkowana. Statystycznie najczęściej około 79\% VAT należnego od sprzedaży opodatkowanej pozostaje w budżecie jst.

Istotnym jest odpowiednie rozpoznanie roli gminnych jednostek organizacyjnych w systemie podatku VAT, które wpływa na gminna gospodarkę finansowa [Bucior, 2014, s. 48]. Wydaje się, że jedynym poprawnym rozwiązaniem w zakresie organizacji scentralizowanych rozliczeń VAT $\mathrm{w}$ jst jest przyjęcie, że wszystkie wpływy $z$ transakcji dokonywanych przez jst (za pośrednictwem jednostek organizacyjnych), łącznie z VAT należnym stanowiącym element ceny transakcyjnej, powinny stanowić dochód budżetowy. Tym samym jednostki organizacyjne, przekazując jednostce nadrzędnej całość wpływów z tego tytułu, powinny ujmować je jako dochód budżetowy i wykazywać w sprawozdaniu Rb-27S. Natomiast zapłata zobowiązania podatkowego VAT, będąca zobowiązaniem jst powinna być finansowana z budżetu jst, a zatem powinna być także budżetowana jako wydatek budżetowy. Inne rozwiązanie wydaje się naruszać zasady gospodarki finansowej jst i jednostek budżetowych zapisane w ustawie o finansach publicznych. Może to negatywnie wpływać na rzetelność sprawozdań budżetowych, które powinny w możliwie największym stopniu prezentować rzeczywiste dane o finansach jednostki samorządu terytorialnego.

$\mathrm{Na}$ problemy z wiarygodnością i porównywalnością danych finansowych poszczególnych jst zwraca uwagę także M. Truszkowska-Kurstak [2017, s. 340], która wskazuje, że skutkiem stosowanych w jst praktyk w zakresie centralizacji rozliczeń VAT sa zniekształcenia i niewypełnianie w zakresie sprawozdawczości budżetowej dostatecznie ani kryterium porównywalności, ani też kryterium przejrzystości finansów publicznych.

\section{Podsumowanie}

Główną przyczyną centralizacji rozliczeń VAT w jednostkach samorządu terytorialnego jest wskazanie, że poszczególne jednostki budżetowe nie mają dostatecznej samodzielności, tj. nie mają osobowości prawnej, a gospodarka finansowa jest ściśle 
powiązana $z$ budżetem jednostki samorządu terytorialnego. Zobowiązanie jednostek samorządu terytorialnego do centralizacji rozliczeń w jednostkach samorządu terytorialnego nie jest wynikiem odgórnych prac koncepcyjnych władzy centralnej, a inicjatywa jednej z jednostek - Gminy Wrocław.

Działania Ministra Finansów w zakresie koordynacji procesu centralizacji rozliczeń VAT naruszaja podstawowa zasadę gospodarki finansowej jednostek budżetowych. Zgodnie z nia, jednostki budżetowe pobrane dochody odprowadzaja na rachunek odpowiednio dochodów budżetu państwa albo budżetu jednostki samorządu terytorialnego. Wychodząc ze słusznego założenia, że podatek VAT nie stanowi dochodu jednostek samorząqu terytorialnego, Ministerstwo Finansów błędnie wskazało, że dochody uzyskiwane przez samorządy z działalności opodatkowanej VAT powinny być ujmowane w sprawozdaniach budżetowych Rb-27S w kwotach netto (bez podatku VAT). Faktyczne wpływy ze sprzedaży opodatkowanej (uzyskana cena sprzedaży) są kwotą zawierającą VAT. Stanowisko Ministerstwa Finansów opiera się na błędnym założeniu, że podatnik VAT (w tym przypadku jst), naliczając swojemu kontrahentowi wymagany przepisami prawa podatek VAT, uzyskuje wplywy z VAT.

Przy obecnych rozwiązaniach w zakresie centralizacji rozliczeń VAT w samorządach, dane prezentowane przez poszczególne jednostki sektora finansów publicznych objęte obowiązkiem sprawozdawczym z realizacji dochodów budżetowych (odpowiednio Rb-27, Rb-27S, Rb-27ZZ) zawierają dane nieporównywane. W odniesieniu do sprawozdań Rb-27S między poszczególnymi jednostkami samorządu terytorialnego istnieją różnice $\mathrm{w}$ zakresie ujmowania podatku VAT, które istotnie wpływają na wiarygodność tych sprawozdań, a ponadto poddają w wątpliwość możliwość ich porównywania.

\section{Literatura}

Bucior G., 2014, Podmiotowość samorz̨qdowej jednostki budǐetowej w systemie podatku VAT, [w:] Metodyczne aspekty badań w rachunkowości, Lelusz H. (red.), Wydawnictwo Uniwersytetu Warmińsko-Mazurskiego, Olsztyn.

Bucior G., 2016, Neutralność podatku od towarów $i$ ustug w gminie, „Finanse, Rynki Finansowe, Ubezpieczenia”, nr 2/2(80), s. 227-234, DOI: 10.18276/frfu.2016.2. 80/2-24.

Famulska T., Rogowska-Rajda B., 2017, Centralizacja rozliczeń VAT w jednostkach samorzadu terytorialnego - uybrane problemy, Prace naukowe Uniwersytetu Ekonomicznego we Wrocławiu. Relacje fiskalne państwo - samorząd terytorialny, nr 485, s. $108-122$.

Ministerstwo Finansów, 2017, Centralizacja rozliczeń VAT w JST - dodatkowe wyjaśnienia, dokument elektroniczny, http://www.finanse.mf.gov.pl/vat/wyjasnienia-ikomunikaty [data wejścia: 29.01.2018]

Ministerstwo Finansów, 2017, pismo z dnia 30 listopada 2017 r. o sygn. BP1.4102. 39.2017 (niepublikowane). 
Ministerstwo Finansów, 2018, pismo z dnia 16 lutego 2018 r. o sygn. FG6.412.7. 2018.KSS (niepublikowane).

Prezydent Miasta Zabrze, 2018, pismo OR-III.1431.24.2018 z dnia 12 lutego 2018 r.

Pyrz M., 2015, Gmina jako platnik podatku od towarów i ustug, [w:] Acta Erasmiana X: $Z$ badań nad prawem, administracja i myśla polityczna, Sadowski M. (red.), Wydział Prawa, Administracji i Ekonomii Uniwersytetu Wrocławskiego, Wrocław, s. 75-87, http://www.repozytorium.uni.wroc.pl/Content/65431/006_Pyrz_Michal_Gmin a_jako_platnik_podatku_od_towarow_i_uslug.pdf [data wejścia: 10.02.2018].

Sąd Najwyższy, Uchwała z dnia 21 lipca 2016 o sygn. akt III CZP 54/06, http://www.sn.pl/sites/orzecznictwo/Orzeczenia1/III\%20CZP\%2054-06.pdf [data wejścia: 29.01.2018]

Truszkowska-Kurstak M., 2017, Wiarygodność sprawozdawnczości gminy dla celów zarz̨adcaych w swietle centralizacji rozliczeńn podatku VAT, Prace naukowe Uniwersytetu Ekonomicznego we Wrocławiu, „Problemy ekonomii, polityki ekonomicznej i finansów publicznych", nr 475, s. 331-342, DOI: 10.15611/pn.2017.475.28.

Ustawa z dnia 13 listopada 2003 r. o dochodach jednostek samorządu terytorialnego, tekst jednolity: Dz. U. 2017 poz. 1453.

Ustawa z dnia 27 sierpnia 2009 r. o finansach publicznych, tekst jednolity: Dz. U. 2017 poz. 2077.

Ustawa z dnia 9 maja 2014 r. o informowaniu o cenach towarów i usług, Dz. U. 2017 poz. 1830. 